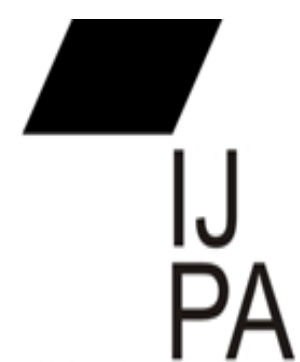

ISSN $2460=0369$

\title{
REFORMASI SISTEM BIROKRASI DALAM PELAYANAN PERIZINAN DI PEMERINTAHAN KOTA KUPANG
}

\author{
William Djani, Maria Magdalena Lino \\ Jurusan Ilmu Administrasi Negara FISIP \\ Unversitas Nusa Cendana Kupang \\ williamdjani@gmail.com
}

\begin{abstract}
This paper is intended to provide answers to some bureaucratic reform efforts related to systems and procedures in public services in Kupang City. Indonesia's public bureaucracy has undergone significant reform, which is a result of the convergence of external and internal factors in supporting change. Bureaucratic reform can be classified into three groups, namely institutional reform, apparatus resource reform and system and procedure reform. This review \& review on the dimensions of Systems and procedures, which provide an evaluation of bureaucratic reforms carried out in the previous decade. The contents and spirit of bureaucratic reform reflect a new understanding of bureaucracy that is very different from the classical form of bureaucracy. As such, it has the potential to bring considerable change, not only in the role of the national public bureaucracy, but in the relations of systems and procedures. However, this study discusses the commitment of the Kupang City Government and the application of systems and procedures as a hindering factor in implementing effective bureaucratic reform.
\end{abstract}

Keywords: Bureaucracy, System and procedure reform, Public Service.

Abstrak, Tulisan ini dimaksudkan untuk memberikan jawaban atas beberapa upaya reformasi birokrasi terkait sistem dan prosedur dalam pelayanan publik di Kota kupang. Birokrasi publik Indonesia telah mengalami reformasi secara signifikan, yang merupakan hasil dari konvergensi faktor eksternal dan internal dalam mendukung perubahan. Reformasi birokrasi dapat diklasifikasikan menjadi tiga kelompok yaitu reformasi kelembagaan, reformasi sumberdaya aparatur dan reformasi sistem dan prosedur. Kajian \& ulasan ini pada dimensi Sistem dan prosedur, yang memberikan evaluasi terhadap reformasi birokrasi yang dilakukan dalam dekade tahun sebelumnya. Isi dan semangat reformasi birokrasi mencerminkan pemahaman baru birokrasi yang sangat berbeda dari bentuk birokrasi klasik. Dengan demikian, memiliki potensi untuk membawa perubahan yang cukup besar, tidak hanya dalam peran birokrasi publik secara nasional, tetapi dalam hubungan Sistem dan prosedur. Namun demikian, kajian ini membahas komitmen Pemerintah Daerah Kota Kupang dan penerapan sistem dan prosedur sebagai faktor yang menghambat dalam pelaksanaan reformasi birokrasi yang efektif.

Kata kunci: Birokrasi, Reformasi Sistem dan prosedur, Pelayanan Publik. 


\section{PENDAHULUAN}

Kegagalan public service dapat mengakibatkan krisis yang ditunjukan dengan adanya "neo-patrimonialism," sebagian orang menyebut "personal rule", dan sebagian memberi label "prebendalism" (Robinson and Persons, 2006:101). Sejumlah negara di Afrika mengalami permasalahan pelayanan publik yang tidak sesuai harapan publik. Kebijakan publik yang ditandai dengan personal rule dengan model dukungan politik melalui clientelism dan logika patriomonialism ke dalam birokrasi telah menyebabkan kerusakan Negara untuk mengembangkan kapasitasnya sebagai developmental state dan menciptakan lingkungan ekonomi yang unpredictable; Larmour (1988) dalam Parmusinto dan Latif (2011). Dengan kata lain fenomena kinerja sektor publik yang buruk di Afrika diakibatkan oleh buruknya lembaga birokrasi dan kebijakan publik (Robinson and Parsons, 2006:102; see also Collier and Gurning, 1999). Birokrasi juga dipandang sebagai penghambat inovasi pemerintahan, sehingga perlu dipikirkan sebuah pendekatan dalam memecahkan masalah publik. World Bank (1992:45) menegaskan pentingnya good governance sebagai respon atas adanya indikasi " crisis of governance sebagai solusi.

Mengkaji birokrasi pada level pemerintah pusat maupun daerah memperlihatkan sebuah kondisi obyektif dari iklim kerja birokrasi selama ini masih dipengaruhi oleh teori atau model birokrasi klasik yang diperkenalkan oleh Taylor, Wilson, Weber, Gullick, dan Urwick, yang dikutip oleh Sinambela dkk (2006:35) yaitu (1) struktur, (2) hierarki, (3) otoritas, (4) sentralisasi. Meskipun model tersebut memaksimumkan nilai efisiensi, efektivitas dan ekonomi, tetapi pada kenyataannya teori tersebut tidak dapat memberikan jawaban secara faktual sesuai dengan banyak temuan penelitian di berbagai tempat.

Birokrasi Indonesia masih menimbulkan permasalahan dan belum fungsional. Berbagai kasus menunjukan pencampuradukan antara birokrasi dengan kekuasaan. Berbagai peraturan yang sudah disepakati masih terabaikan, sehingga menimbulkan banyak keluhan dari masyarakat tentang lemahnya pelayanan publik. Hasil studi Ichsan (2008) dalam Pandie (2009) mencatat bahwa birokrasi perizinan menjadi salah satu penghalang utama investasi di Indonesia. Di banding dengan negara-negara ASEAN, birokrasi perizinan sangat buruk dengan jumlah prosedur 19, lama pengurusan perijinan 196 hari dengan biaya sekitar 286,9 persen dari pendapatan per kapita. Selanjutnya, 
menurut studi dari International Bank Reconstruction and Development dan Bank Dunia, Indonesia di tahun 2009 berada diurutan 122 dari 138 negara dalam hal kinerja pemerintah dalam mendukung perekonomian, khususnya menyangkut pendirian usaha, pengurusan izin mendirikan bangunan, dan pendaftaran properti. Khusus untuk mengurus mendirikan usaha, pengusaha harus melalui prosedur yang panjang, waktu yang lama dan biaya yang mahal (Dwiyanto, 2011). Studi Eko Prasojo \& Nugroho, (2008) dalam Pandie (2009) berhasil mengidentifikasi terdapat 1.850 peraturan yang tumpang tindih dan 388 pelayanan yang tumpang tindih pula. Semua persoalan tersebut mengakibatkan pelayanan perizinan investasi dan pengembangan usaha di Indonesia sangat mahal, berbelit, lambat, kental dengan suap.

Pada level Pemerintah Kota Kupang, reformasi birokrasi terkait sistem dan prosedurnya yaitu bagaimana keberadaan Standard Operasional Prosedur (SOP) untuk mendukung pelayanan publik. Birokrasi Pemerintahan Kota Kupang memiliki SOP, dengan sebutan Standar Pelayanan (SP) sesuai Keputusan Kepala Badan Pelayanan Terpadu Kota Kupang Nomor: BPPT.800/KEP/404.a/XII/2013, yang merupakan produk Dinas Penanaman Modal dan Pelayanan Perizinan Terpadu Kota Kupang, lebih mengakomodir kepentingan birokrasi dari pada masyarakat. Permasalahannya adalah belum dilakukan uji publik dengan melibatkan stakeholders sehingga menghasilkan sebuah standar pelayanan yang dapat memberikan kemudahan bagi publik.

Sistem dan prosedur, terkait dengan standar pelayanan (SP) yang merupakan berbagai pentahapan dalam proses perizinan agar lebih transparan dari sisi biaya, untuk setiap objek perizinan, dan durasi penyelesaian proses perizinan yang mengatur beberapa hal penting meliputi persyaratan pelayanan, mekanisme dan prosedur, biaya serta durasi/waktu penyelesaian untuk setiap jenis perizinan. Walaupun telah memiliki sistem dan prosedur oleh Birokrasi Pelayanan Perizinan Terpadu Kota Kupang akan tetapi sejumlah permasalahan pelayanan publik terkait izin usaha, oleh pengusaha kecil tentang lambannya pengurusan izin, prosedur yang panjang sehingga menyulitkan para pengusaha kecil untuk mendapatkan izin usaha yang legal. Data hasil kajian yang dilakukan oleh lembaga Penelitian Undana bekerja sama dengan The Asia Foundation (2009) di Kota Kupang menunjukan bahwa sistem dan prosedur pelayanannya mencapai 84,75 persen namun indikator yang dikenakan mengalami penurunan menjadi 
70,8 persen. Upaya yang dilakukan tersebut adalah sebagai reformasi birokrasi untuk dapat meningkatkan kinerjanya dalam bidang pelayanan publik.

Birokrasi pemerintah daerah di Kota Kupang khususnya pada Lembaga Pelayanan Perizinan terpadu sebagai Organisasi Perangkat Daerah (OPD) yang berada pada lingkup pemerintah Kota Kupang masih memiliki permasalahan terkait sistem dan prosedur, sehingga memerlukan reformasi. Oleh karena itu, pengkajian terhadap sistem dan prosedur dalam birokrasi merupakan suatu upaya merespons kebutuhan dan permasalahan publik dalam meningkatkan kualitas pelayanan publik. Hasil kajian Piar NTT (2012) menemukan sejumlah pengusaha kecil dibidang kelautan yang telah beberapa kali mengurus izin usaha namun mengalami permasalahan, untuk memiliki izin secara legal. Sebagian besar pengusaha kecil dan menengah yang mengurus izin mengalami hambatan karena banyak mekanisme dan aturan dalam pengurusan. Erende Pos (2011) mengungkapkan bahwa masih banyak pengusaha di Kota Kupang belum mengantongi izin usaha, yang disebabkan sejumlah persyaratan terkesan prosedural dan memberatkan pengusaha, dan kewajiban memiliki sertifikat tanah sebagai syarat administratif.

\section{KAJIAN TEORITIS}

Reformasi Birokrasi pada dimensi sistem dan prosedur kerja meliputi standard operating procedure, changing methods, processes, techniques, routes, functions, roles, contacts, controls, transparent (Caiden, 1991, Caiden 2011; Pollit and Bouckaert, 2000; Hughes 1998; Smith, 2007). Selain itu, sistem dan prosedur kerja mengacu pada prinsip good governance yang menekankan pada transparansi, akuntabilitas dan partisipasi masyarakat. Melalui standar operasional prosedur (SOP) dijamin adanya transparansi, sebab masyarakat tahu mekanisme alur pelayanan publik, serta terbuka bagi masyarakat untuk menyampaikan keluhan dan informasi balik tentang perlakuan pelayanan melalui Indeks Kepuasan Masyarakat (IKM). Jika penyelenggaraan pelayanan publik diukur dengan nilai-nilai yang baik, maka akan menggunakan sistem pelayanan secara bersungguh-sungguh seperti tujuan yang diharapkannya, penggunaan tehnologi informasi komunikasi (TIK), serta ketersediaan sarana dan prasarana. Dalam mekanisme ini, juga terbangun model kemitraan dalam proses pelayanan antara lembaga birokrasi dan lembaga teknis, sehingga pelayanan publik berlangsung dalam 
koridor profesionalisme birokrasi. Birokrasi pemerintah perlu metode pengorganisasian pekerjaan dan mekanisme pengendaliannya, melakukan revitalisasi, termasuk reposisi peran birokrasi dalam rangka meningkatkan kualitas birokrasi bagi publik.

Salah satu aspek penting untuk mewujudkan birokrasi yang efektif, efisien dan akuntabel dalam rangka perbaikan kinerja manajemen pemerintahan/kualitas pelayanan publik adalah dengan memperbaiki proses penyelenggaran administrasi pemerintahan melalui penyusunan dan penerapan Standar Operasional Prosedur (SOP) Administrasi Pemerintahan. PermenPAN Nomor: PER/21/M.PAN/11/2008 bahwa Standar Operasional Prosedur (SOP) adalah serangkaian instruksi tertulis yang dibakukan mengenai berbagai proses penyelenggaraan administrasi pemerintahan, bagaimana dan kapan harus dilakukan, dimana dan oleh siapa dilakukan. Menurut Atmoko, (2006) Standar Operasional Prosedur merupakan suatu pedoman atau acuan untuk melaksanakan tugas pekerjaan sesuai denga fungsi dan alat penilaian kinerja instansi pemerintah berdasarkan indikator-indikator teknis, administratif dan prosedural sesuai tata kerja, prosedur kerja dan sistem kerja pada unit kerja yang bersangkutan.

Reformasi birokrasi akan berjalan pincang sehingga lamban untuk mencapai tujuannya jika tidak terdapat penataan ketatalaksanaan. Ketatalaksanaan adalah roda yang menggerakkan birokrasi dalam menyelenggarakan pemerintahan maupun pelayanan kepada masyarakat. Kamus Bahasa Indonesia (KBI) dalam Sedarmayanti (2010:88) memberikan definisi "tata laksana yaitu cara mengurus (menjalankan, melaksanakan) aktivitas usaha (perusahaan). Ketatalaksanaan merupakan cara melakukan kerjasama dalam rangka pelaksanaan tugas organisasi.

Penataan ketatalaksanaan yang merupakan bagian dari reformasi birokrasi pasti mempunyai tujuan. Tujuan penataan ketatalaksanaan tidak lain untuk menciptakan tata prosedur, mekanisme dan sistem kerja yang efektif dan efisien dalam menyelenggarakan pemerintahan dan pelayanan kepada masyarakat. Adapun tujuan pedayagunaan ketatalaksanaan menurut Sedarmayanti (2010:88) ada dua yaitu, mewujudkan tata laksana yang ringkas atau simpel, efektif, efisien dan transparan dan memberikan pelayanan prima serta memberdayakan masyarakat. Penataan ketatalaksanaan yang lebih menitikberatkan pada sistem tata kelola, prosedur dan mekanisme kerja aparatur pemerintahan akan cenderung sulit untuk dilaksanakan. Kebiasaan kerja kurang efektif dan efisien yang melekat pada birokrasi akan 
mempengaruhi penataan ketatalaksanaan dalam reformasi birokrasi. Perlu strategi yang tepat dalam pengimplementasian penataan ketatalaksanaan agar tepat sasaran.

Standar Operasional Prosedur Administrasi Pemerintahan (SOP-AP) sudah menjadi bagian dari unsur birokrasi yang ideal. Menurut Weber dalam Thoha (2007:18) salah satu unsur birokrasi yang ideal yaitu adanya peraturan formal yang menjadi pengendalian dan pengawasan dalam kinerja pejabat di suatu birokrasi. Aturan formal menjadi sesuatu yang penting dan dijadikan dasar untuk menjalankan tugas-tugas organisasi dalam mencapai tujuannya. Di zaman globalisasi ini hampir semua birokrasi pemerintahan yang ada pasti mempunyai aturan formal.

Dilihat dari fungsinya, SOP berfungsi membentuk sistem kerja dan aliran kerja yang teratur, sistematis, dan dapat dipertanggungjawabkan; menggambarkan bagaimana tujuan pekerjaan dilaksanakan sesuai dengan kebijakan dan peraturan yang berlaku; menjelaskan bagaimana proses pelaksanaan kegiatan berlangsung; sebagai sarana tata urutan dari pelaksanaan dan pengadministrasian pekerjaan harian sebagaimana metode yang ditetapkan; menjamin konsistensi dan proses kerja yang sistematik; dan menetapkan hubungan timbal balik antar satuan kerja. Penyusunan SOP harus menjalankan tahapan, seperti: persiapan, penilaian kebutuhan, pengembangan, integrasi dan manajemen serta monitoring dan evaluasi yang ada di dalam Permenpan Nomor 21 Tahun 2008 tentang Pedoman Penyusunan Standar Operasional Prosedur (SOP) Administrasi Pemerintahan. Apa yang ada di dalam Permenpan tersebut juga sebenarnya telah berdasarkan teori penyusunan SOP yang ada. Hal tersebut oleh Tambunan (2011) bahwa Standard Operating Procedures memuat tahap-tahap teknis penyusunan SOP mulai dari tahap persiapan sampai tahap pemeliharaan dan audit yang merupakan acuan bagi birokrasi dalam menjalankan tugas dan fungsi.

Dalam teori hukum organisasi pemerintahan terdapat teori perbaikan dan reformasi birokrasi merupakan suatu kegiatan yang berkesinambungan dengan didukung komitmen seorang pemimpin. Kehadiran Undang-Undang Nomor 25 Tahun 2009 tentang Pelayanan Publik, disusul UU No 5/2014 tentang Aparatur Sipil Negara (ASN), serta UU No 30/2014 tentang Administrasi Pemerintahan (Adpem), merupakan instrumen pokok untuk merealisasikan gagasan revolusi mental birokrasi. UU Pelayanan Publik mengatur proses dan kualitas produk pelayanan publik yang menghubungkan siklus kebutuhan rakyat terhadap kapasitas birokrasi memenuhi 
kebutuhan rakyat terhadap pelayanan publik. UU ASN melakukan reformasi pada level kualitas individu dan kinerja aparat birokrasi. Sementara UU Administrasi Pemerintahan melakukan penataan terhadap prosedur kebijakan birokrasi pemerintah yang selalu harus disandarkan pada legalitas kebijakan berdasarkan peraturan perundang-undangan yang berlaku dan asas-asas umum pemerintahan yang baik. Dengan demikian, tidak boleh ada celah terjadi tindakan penyalahgunaan wewenang ataupun tindakan sewenang-wenang yang terjadi karena kebijakan aparat pemerintah yang melanggar prinsip-prinsip fundamental dalam UU Administrasi Pemerintahan. Keseluruhan produk hukum sebagai landasan bekerjanya sistem birokrasi pemerintah tersebut juga mengharuskan adanya standar operasional prosedur (SOP) terhadap setiap kebijakan pemerintahan sektoral. Apalagi, dengan hadirnya UU No 20/2014 tentang Standardisasi dan Penilaian Kesesuaian juga mensyaratkan eksistensi SOP baku terhadap setiap prosedur kebijakan dan pelayanan publik pemerintah. Kehadiran UU Administrasi Pemerintahan tersebut merupakan sebuah terobosan yang besar terhadap sistem administrasi pemerintahan di Indonesia. Keberadaan UU Administrasi Pemerintahan dapat memperkuat sinergi administratif dalam tata kelola birokrasi pemerintahan. UU Administrasi Pemerintahan menjadi rujukan utama para birokrat dalam melaksanakan kewenangannya dan tidak lagi hanya bersandar pada UU sektoral, yang selama ini telah memicu terjadi sekat-sekat sektoralisme. Dalam teori hukum administrasi negara, bagi para birokrat, UU Administrasi Pemerintahan menjadi norma fundamental, urat nadi pelaksanaan kewenangan administratif yang dimilikinya. UU Administrasi Pemerintahan mengisi kekurangan norma sebagai dasar pengujian terhadap legalitas tindakan administratif. Sementara bagi rakyat, UU Adpem sebagai parameter untuk menilai kelayakan tindakan administratif yang dilakukan para pejabat administrasi negara.

Dwiyanto (2011:62) bahwa dalam konteks birokrasi publik perlu adanya peraturan dan prosedur yang jelas sehingga membuat warga negara pengguna layanan dapat mengetahui hak dan kewajibannya untuk memperoleh pelayanan. Berapa banyak masyarakat harus membayar harga pelayanan, berapa lama harus menunggu, dan apa pelayanan yang akan diterima. Apa yang dapat dilakukan jika pelayanan yang diterima ternyata tidak seperti yang dijanjikan? Semua itu harus dapat diketahui oleh warga pengguna layanan dengan pasti. Warga negara berada dalam posisi yang sangat lemah. 
Bagi pejabat birokrasi, tidak adanya prosedur dan aturan yang jelas juga dapat sangat merugikan karena hal itu berarti mengharuskan untuk selalu mengambil keputusan pada saat melayani warga. Situasi itu menghadapkan pada peluang dan resiko untuk melakukan kesalahan dalam pengambilan keputusan.

\section{METODE PENELITIAN}

Jenis Penelitian ini menggunakan pendekatan kualitatif yang bertujuan untuk mendeskripsikan dan memperlihatkan suatu fenomena terkait reformasi birokrasi dalam dimensi sistem dan prosedur, dengan beberapa fokus/aspek yang diteliti adalah: (a) Persyaratan Pelayanan, (b) Standar pelayanan tentang persyaratan, (c) waktu yang dibutuhkan dalam proses pengurusan izin yang dilimpahkan, (d) Mekanisme pengaduan \& Penyelesaian komplain.

Sumber data penelitian ini terdiri dari informan, peristiwa dan dokumen. Informan adalah orang-orang yang dianggap mengetahui secara benar suatu fenomena yang menjadi obyek penelitian, sehingga dapat membantu peneliti dalam menggali informasi yang dibutuhkan; (Anselm,. 1987). Informan dalam penelitian ini terdiri dari: Inside Governmemt yaitu para pihak yang terlibat dalam Reformasi Birokrasi Kota Kupang dan Outside Government yaitu para pihak/kelompok pengguna pelayanan perizinan (pengusaha dan masyarakat) di Kota Kupang. Kemudian peristiwa yaitu keadaan yang terjadi terkait dengan penelitian ini, dan sumber data dokumen yaitu berupa data sekunder yang diperoleh dari situs-situs penelitian yang telah ditetapkan.

Tehnik pengumpulan data dalam penelitian ini adalah: Observasi, Wawancara, dan Tehnik Dokumentasi. Sementara tehnik analisis data yang dilakukan dengan menggunakan analisis kualitatif dengan mengikuti langkah-langkah yang dikemukakan Miles, Huberman \& Saldana, (2014) meliputi: analisis tiga arus bersamaan kegiatan: (1) kondensasi data, (2) display data, dan (3) penarikan kesimpulan/verifikasi yang merupakan suatu proses/ siklus interaktif. Komponen-komponen analisis data tersebut di atas oleh Miles dan Huberman (2014) di gambarkan sebagai berikut: 


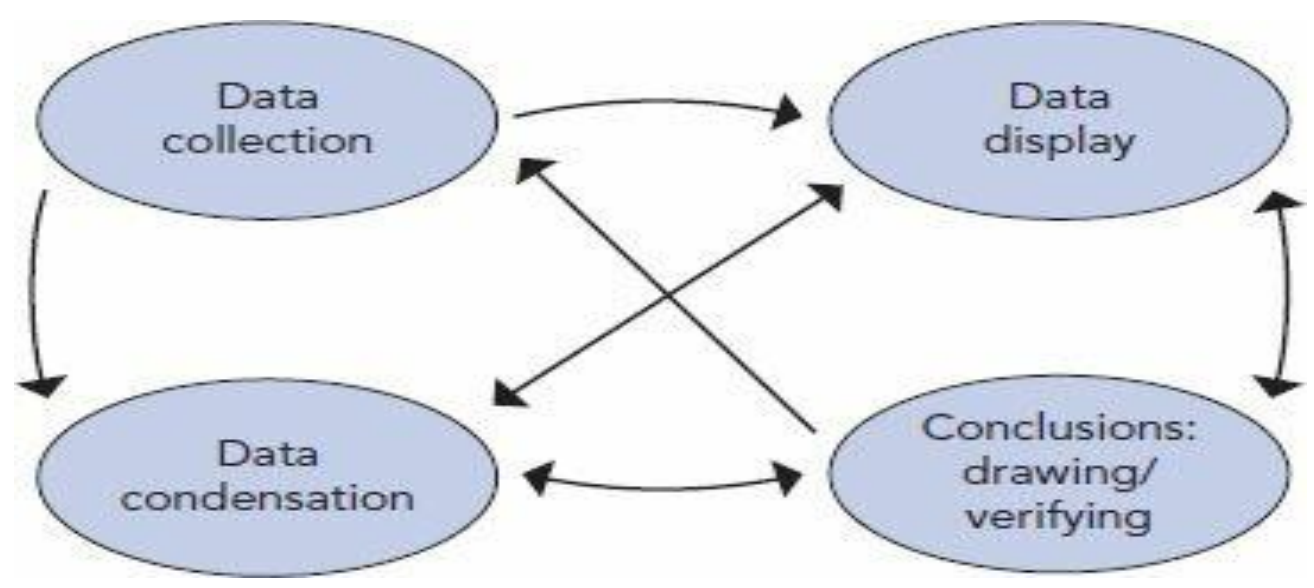

\section{Gambar: 3.1. Analisis Data Model Interaktif}

Source: Miles, M. B., Huberman, A. M., \& Saldana. Qualitative data analysis: An expanded sourcebook (2nd ed.). Thousand Oaks, CA: Sage Publications. $(2014,33)$.

\section{PEMBAHASAN}

Sistem dan prosedur dalam sebuah organisasi merupakan arah bagi pencapaian tujuan organisasi secara efektif, yang jika dijalankan dengan orang-orang yang memiliki perilaku yang baik akan meningkatkan kinerja atau hasil yang baik pula. Deskripsi Standar Operasional Prosedur (SOP) secara umum di Pemerintah Kota Kupang dan secara khusus di Birokrasi Pelayanan Perizinan Terpadu Kota Kupang.

Pemerintah Kota Kupang telah memiliki Standard Operasional Prosedur (SOP) sesuai Peraturan Walikota Kupang tentang Standar Operasional Prosedur (SOP) pada SKPD di lingkungan Pemerintah Kota Kupang seperti pada tabel berikut:

\section{Tabel 1. Jenis SOP pada lingkup Pemerintah Kota Kupang}

\begin{tabular}{|l|l|l|}
\hline No & \multicolumn{1}{|c|}{ Jenis SOP } & lkum \\
\hline 1 & $\begin{array}{l}\text { Pelayanan Perizinan dan Non perizinan di Kecamatan dan } \\
\text { Kelurahan Lingkup Pemerintah Kota Kupang }\end{array}$ & $\begin{array}{l}\text { Peraturan Walikota } \\
\text { Kupang Nomor 16 } \\
\text { Tahun 2011 }\end{array}$ \\
\hline 2 & $\begin{array}{l}\text { Pelayanan Administrasi Pemerintahan pada Satuan Kerja } \\
\text { Perangkat Daerah (SKPD) }\end{array}$ & $\begin{array}{l}\text { Peraturan Walikota } \\
\text { Kupang Nomor 16 } \\
\text { Tahun 2012 }\end{array}$ \\
\hline 3 & Standar Kerja 5 hari kerja dalam seminggu & $\begin{array}{l}\text { Peraturan Walikota } \\
\text { Kupang Nomor 11 } \\
\text { Tahun 2009 }\end{array}$ \\
\hline 4 & Standar Pelayanan Publik Pemerintah Kota Kupang. & $\begin{array}{l}\text { Peraturan Walikota } \\
\text { Kupang Nomor: 12 } \\
\text { Tahun 2013 }\end{array}$ \\
\hline 5 & Standar Pelayanan Minimal Pemerintah Kota Kupang & $\begin{array}{l}\text { Peraturan Walikota } \\
\text { Kupang Nomor: 16A } \\
\text { Tahun 2013 }\end{array}$ \\
\hline
\end{tabular}

Sumber: Olahan Dokumen Road Map Reformasi Birokrasi Pemerintah Kota Kupang 
Pemerintah Kota Kupang memiliki 5 jenis SOP sesuai Keputusan Walikota Kupang Nomor: 114B/KEP/HK/2013 tentang Tim Koordinasi Percepatan Penerapan Standar pelayanan Minimal di lingkungan Pemerintah Kota Kupang. Tim koordinasi ini belum dapat melaksanakan fungsinya secara efektif, disebabkan karena keterbatasan anggaran untuk melaksanakan sosialisasi SOP. Demikian pula penerapannya di lingkup Pemerintahan Kota Kupang mengalami hambatan, yang sesuai hasil penelitian bahwa Pemerintah Kota Kupang telah memiliki SOP akan tetapi belum semua Organisasi Perangkat Daerah (OPD) menerapkannya karena belum memahami secara benar isi SOP, sehingga membutuhkan sosialisasi yang berkelanjutan.

Pentingnya SOP sebagai arah dalam pelayanan birokrasi, sehingga membutuhkan perhatian untuk mengurangi perintah/instruksi dari pihak pimpinan yang selama ini dilaksanakan dalam menggerakan staf, sistem dan prosesur mengatur apa yang dikerjakan pimpinan dan staf, namun permasalahan yang dihadapi adalah keterbatasan anggaran untuk sosialisasi dan kurangnya komitmen dari unsur pimpinan dalam aplikasinya. Hasil penelitian menunjukan bahwa walaupun pemerintah Kota Kupang telah memiliki Standard Operasional Prosedur (SOP), akan tetapi belum berjalan secara efektif disebabkan keterbatasan anggaran.

Birokrasi Pelayanan Perizinan Terpadu Kota Kupang sebagai salah satu Organisasi Perangkat Daerah (OPD) yang bergerak dalam pelayanan perizinan yang diteliti terkait reformasi birokrasi dalam dimensi sistem dan tata laksana dalam birokrasi Perizinan Terpadu Kota Kupang, menunjukan bahwa sistem dan tata laksana birokrasi pelayanan perizinannya telah dirumuskan sebagai dasar dalam pelayanan publiknya. Standar Pelayanan Birokrasi Pelayanan Perizinan Terpadu Kota Kupang berdasarkan Keputusan Kepala Badan Pelayanan Perizinan Terpadu Kota Kupang Nomor: BPPT.800/KEP/404.a/XII/2013 terhadap izin yang dikelolanya. Sistem dan prosedur yang ditetapkan dengan keputusan tersebut disebut Standar Pelayanan (SP), merupakan acuan bagi Birokrasi Kota Kupang dalam melaksanakan tugas dan fungsi sebagai lembaga yang mengemban misi publik. Standar pelayanan ini memuat beberapa komponen penting sebagai acuan bagi birokrasi pelayanan publik dan masyarakat sebagai pengguna pelayanan yaitu: (a) Dasar hukum, (b) Persyaratan Pelayanan, (c) Sistem Mekanisme dan Prosedur, (d) Jangka waktu penyelesaian, (e) Biaya/Tarif, (f) Produk Pelayanan,(g) Sarana, Prasarana dan/atau fasilitas, (h)Kompetensi Pelaksana, (i) 
Pengawasan Internal, (j) Penanganan Pengaduan, saran dan masukan, (k)Jumlah Pelaksana, (1) Jaminan Pelayanan, (n) Jaminan Keamanan dan keselamatan pelayanan, (m) Evaluasi Kinerja Pelayanan.

Hasil penelitian menunjukan bahwa Badan Pelayanan Perizinan Terpadu (BPPT) Kota Kupang telah memiliki Standar Pelayanan (SP) terhadap 13 jenis izin yang dikelolanya yang meliputi Surat izin tempat usaha (SITU), Surat izin usaha perdagangan (Siup), Tanda daftar perdagangan (TDP), Tanda daftar gudang (TDG), Tanda daftar industri (TDI), Izin usaha industri (IUI), Surat izin tempat usaha minuman berakhol (Situ MB), Surat izin usaha perdagangan minuman berakhol (Siup MB), Izin trayek (ITAK), Fiskal, Advis Plan, Izin membangun (IMB) dan reklame yaitu terkait persyaratan pengurusan izin, besaran biayanya dan alokasi waktu dalam penyelesaian dokumen perizinan, yang memiliki variasi. Jika dilihat dari sisi persyaratan, IMB menduduki peringkat pertama dengan 12 persyaratan, kemudian disusul oleh Izin Tempat Usaha (SITU) dengan jumlah persyaratan sebanyak 9, dan yang paling sedikit jumlah persyaratannya adalah izin fiskal dengan jumlah 4 persyaratan. Demikian juga biaya dokumen izin dan waktu penyelesaiannya yang paling banyak IMB, kemudian yang paling sedikit adalah izin trayek.

Standar Pelayanan (SP) Badan Pelayanan Perizinan Terpadu Kota Kupang ini sebagai dasar untuk mengatur hal-hal terkait dengan pelayanan perizinan. Kajian dokumen Keputusan Kepala Badan Pelayanan Perizinan terpadu Kota Kupang Nomor: BPPT.800/KEP/404.a/XII/2013 tentang Penetapan Standar Pelayanan Perizinan Terpadu Kota Kupang, yang bertujuan agar baik aparat BPPT dapat memahami apa yang akan dikerjakan, dan bagi masyarakat memahami bagaimana mengurus sebuah perizinan. SOP merupakan arah bagi aparat birokrasi untuk melaksanakan tugas pokok dan fungsi untuk mengikat semua unsur pegawai yang ada dalam BPPT Kota Kupang dalam melaksanakan pelayanan perizinan taat kepada SOP

Urgensi Standar Operasional Prosedur (SOP) bagi birokrasi pelayanan perizinan terpadu di Kota Kupang, yang dibahas berdasarkan aspek-aspek yang terkandung dalam SOP sebagai berikut:

\section{a. Persyaratan Pelayanan dalam proses perizinan.}

Standar Pelayanan (SP) merupakan acuan bagi aparat birokrasi dalam menjalankan fungsinya. Hasil penelitian menunjukan bahwa standar pelayanan belum 
diterapkan secara optimal yang disebabkan karena aparat birokrasi belum memahami standar pelayanan (SP) dengan sempurna, sehingga membawa kekecawaan bagi masyarakat. Persyaratan pelayanan terhadap perizinan dokumen, masih dinilai memberatkan, hal ini sesuai fakta emipirik bahwa pelayanan perizinan dinilai belum efektif yang disebabkan karena ketidaktepatan waktu pelayanan yang diterima oleh masyarakat, dan prinsip one stop services system belum sepenuhnya diterapkan. Pelayanan perizinan satu pintu (one stop services) jika diterapkan secara baik akan meningkatkan kualitas pelayanan perizinan, dimana semua persyaratan perizinan diperoleh pada Lembaga yang mengelola pelayanan Perizinan terpadu Kota Kupang. Hal ini dilakukan agar masyarakat yang mengurus izin tidak harus melalui banyak pintu. Kondisi idealnya, masyarakat yang mengurus persyaratan izin harus melalui satu pintu, supaya memudahkan masyarakat baik dari segi waktu, biaya dan resiko.

Prinsip pelayanan satu pintu diterapkan secara efektif maka pelayanan publik yang selama ini terkesan birokratis akan menjadi lebih baik, tidak melalui prosedur yang berbelit. Karena itu Standar Pelayanan (SP) sebagai acuan dalam pengelolaan pelayanan perizinan harus mampu memberikan solusi terhadap prosedur pelayanan. Kajian ini membuktikan bahwa penerapan Standard Pelayanan (SP) oleh birokrasi pelayanan perizinan terpadu Kota Kupang yang melalui survey Indeks Kepuasan Masyarakat (IKM) pada tahun 2013, menunjukan bahwa SP belum diterapkan secara efektif, dimana terdapat 5 (lima) unsur dengan nilai dibawah kategori baik yaitu : (a) Kepastian jadwal pelayanan, (b) Prosedur Pelayanan, (c) Kecepatanan petugas pelayanan, (d) Kedisiplinan petugas pelayanan, (e) Persyaratan pelayanan.

Unsur-unsur tersebut memiliki kekurangan, yang harus ditingkatkan dan diperbaiki untuk meningkatkan kualitas pelayanan perizinan pada birokrasi pelayanan terpadu Kota Kupang. Hal ini penting yang harus dilaksanakan adalah perbaikan terhadap unsur pelayanan yang mempunyai nilai paling rendah untuk ditingkatkan. Fakta empirik ini menunjukan bahwa standar pelayanan belum sepenuhnya diterapkan secara baik oleh birokrasi pelayanan, yang ditandai dengan adanya pengeluhan oleh masyarakat sebagai pengguna layanan terhadap lambatnya pelayanan.

\section{b. Keterbukaan dalam Standar Pelayanan}

Keterbukaan dalam standar pelayanan yang baik adalah memudahkan pengguna pelayanan untuk diakses dimanapun dan kapan saja. Hasil penelitian menunjukan 
bahwa standar pelayanan yang dimiliki oleh Birokrasi Publik Kota Kupang selalu dipajang pada papan pengumuman dan termuat dalam brsosur-brosur sehingga memudahkan masyarakat untuk membaca persyaratan-persyaratan pelayanan perizinan. Standar pelayanan yang ditetapkan hendaknya realistis karena merupakan jaminan bahwa janji atau komitmen yang dibuat dapat dipenuhi, jelas dan mudah dimengerti oleh para pemberi dan penerima pelayanan. Informasi pelayanan, untuk memenuhi kebutuhan informasi pelayanan kepada masyarakat, setiap unit pelayanan instansi pemerintah wajib mempublikasikan mengenai prosedur, persyaratan, biaya, waktu, standar, akta/janji, agar diketahui oleh masyarakat.

Standar Pelayanan yang ada di Birokrasi Publik Kota Kupang, bukan sebuah dokumen yang sekedar ada, untuk memenuhi syarat formal dalam tata laksana birokrasi akan tetapi merupakan dasar yang jelas dalam pengelolaan pelayanan perizinan yang mengikat bagi semua anggota organisasi. Memang Birokrasi Publik Kota Kupang telah memiliki Standar Pelayanan, akan tetapi sosialisasi langsung kepada staf masih dirasakan minim, hanya dibuat dalam bentuk brosur dan alur bagan pelayanan yang dipajang pada papan pengumuman.

Keterbukaan pelayanan penting dilakukan, agar aparat birokrasi dan masyarakat dapat memahaminya, tidak hanya dalam bentuk penerbitan brosur dan pajangan lewat papan pengumuman, akan tetapi melalui media-media yang lain. Sejak Birokrasi Perizinan Kota Kupang memiliki SOP tahun 2013 maka dilaksanakan sosilaisasi yang lebih difokuskan kepada masyarakat dengan menggunakan media RRI Kupang, dan juga beberapa kali pertemuan dengan perwakilan masyarakat melalui Kecamatan yang ada di Kota Kupang, sedangkan untuk staf BPPT Kota Kupang biasanya dilaksanakan melalui rapat atau pada saat apel, walaupun frekwensi sosialisasinya masih dirasakan minim.

Keterbukaan standar pelayanan pada Birokrasi Publik Kota Kupang masih memiliki hambatan baik terkait penggunaan tehnologi informasi maupun penyebaran informasi melalui media. Masyarakat sebagai pengguna layanan yang mengurus izin, tidak mengetahui adanya sosialisasi melalui media RRI Kupang, karena kondisi sekarang jarang masyarakat mendengar radio, informasi tentang pelayanan izin, diperoleh dari teman yang pernah mengurus izin, dan juga pada saat masyarakat ke Kantor pelayanan perizinan, mendapatkan informasi dari staf, dan melalui media 
lainnya.

Keterbukaan dalam standar pelayanan pada Birokrasi Publik Kota Kupang belum efektif, hal ini disebabkan karena penggunaan media sosialisasi terhadap standar pelayanan (SP) belum sesuai harapan masyarakat. Di sisi lain Birokrasi Pelayanan Perizinan Terpadu Kota Kupang belum memiliki website tersendiri untuk dapat diakses oleh masyarakat secara luas.

\section{c. Waktu yang dibutuhkan dalam pengurusan izin}

Waktu yang dibutuhkan untuk sebuah proses pelayanan perizinan disesuaikan dengan standar pelayanan, sehingga tidak mengecewakan masyarakat sebagai pengguna pelayanan. Kajian ini menunjukan bahwa masih terlihat kekecewaan masyarakat akan keterlambatan penandatanganan dokumen izin, yang disebabkan karena kesibukan pimpinan dalam menghadiri rapat-rapat baik pada level pemerintah Kota Kupang maupun rapat secara intern organisasi Birokrasi Publik Kota Kupang. Lama waktu yang dibutuhkan dalam proses pelayanan perizinan disesuaikan standar pelayanan yaitu 1 hari, atau lebih disesuaikan kelengkapan persyaratan yang dipenuhi oleh masyarakat. Jika persyaratannya tersedia secara lengkap dan pimpinan berada di tempat maka dokumen izinnya bisa diterbitkan. Izin-izin yang bersifat kajian teknis membutuhkan koordinasi dengan instansi terkait, untuk dilakukan analisa teknis dan survey secara mendalam.

Jika dicermati fakta empiris ini yang dikaitkan dengan persepsi birokrasi dan masyarakat terkait ketepatan waktu pelayanan akan menunjukan adanya perbedaan. Pandangan aparat birokrasi selalu berbeda dengan pandangan masyarakat karena selalu menjaga nama baik dan citra lembaganya, walaupun kinerja birokrasi terkadang mengecawakan masyarakat. Sebagai pengguna pelayanan dalam urusan perizinan tempat usaha dan izin usaha bahwa lamanya waktu yang dibutuhkan dalam sebuah proses perizinan melalui beberapa tahapan yaitu dari Rukun Tetangga/Rukun Wilayah, kemudian ke Lurah, pengesahan Camat, yang selanjutnya diteruskan ke Birokrasi Pelayanan Perizinan Terpadu Kota Kupang untuk diproses dokumen izin. Lamanya waktu untuk sebuah proses penerbitan dokumen izin sangat tergantung kehadiran pimpinan, yang tidak disibukan dengan kegiatan lain misalnya menghadiri rapat-rapat, atau tugas kedinasan lainnya. Alokasi waktu yang dibutuhkan dalam pengurusan perizinan sesuai dengan SOPnya rata-rata 3 hari, kecuali izin mendirikan bangunan 
yang membutuhkan waktu 14 hari, disebabkan karena masih melalui kajian teknis dan survey lapangan. Hasil kajian menunjukan belum sepenuhnya SOP diterapkan secara efektif, terkait dengan waktu penyeslesaian izin yang masih melebihi standar yang ditetapkan.

\section{d. Mekanisme Pengaduan \& Penyelesaian komplain oleh masyarakat}

Hasil penelitian menunjukan bahwa Birokrasi Publik Kota Kupang memiliki media dalam bentuk kotak saran sebagai sarana pengaduan kepada birokrasi pelayanan perizinan terpadu Kota Kupang, akan tetapi solusi terhadap pengaduan publik, belum memberikan hasil yang memuaskan yang disebabkan karena pengaduan-pengaduan yang ada hanya melalui rapat secara intern lembaga untuk selanjutnya melakukan perbaikan-perbaikan.

Kajian ini menunjukan bahwa pengaduan yang masuk berupa surat ataupun pengaduan yang disampaikan langsung pada tahun 2013 sebanyak 250 buah pengaduan, dan yang mendapat solusi sebanyak 41 buah pengaduan. Jika dilihat dari kinerja birokrasi dalam penyelesaian pengaduan hanya sekitar $16 \%$. Walaupun kondisi ini terjadi dimasa reformasi, pemenuhan atas tuntutan pengguna jasa oleh aparat birokrasi justru yang paling rendah. Bahkan secara keseluruhan kasus sebanyak 250 buah, sama sekali kurang mendapat respons konkrit dari birokrasi. Hal tersebut semakin memberikan indikasi bahwa harapan reformasi akan dapat memenuhi tuntutan masyarakat, terutama terkait perbaikan kualitas pelayanan publik dari birokrasi masih jauh dari kenyataan. Mekanisme pengaduan oleh masyarakat kepada birokrasi pelayanan perizinan terpadu Kota Kupang dapat dilihat pada bagan mekanisme pengaduan sbb: 


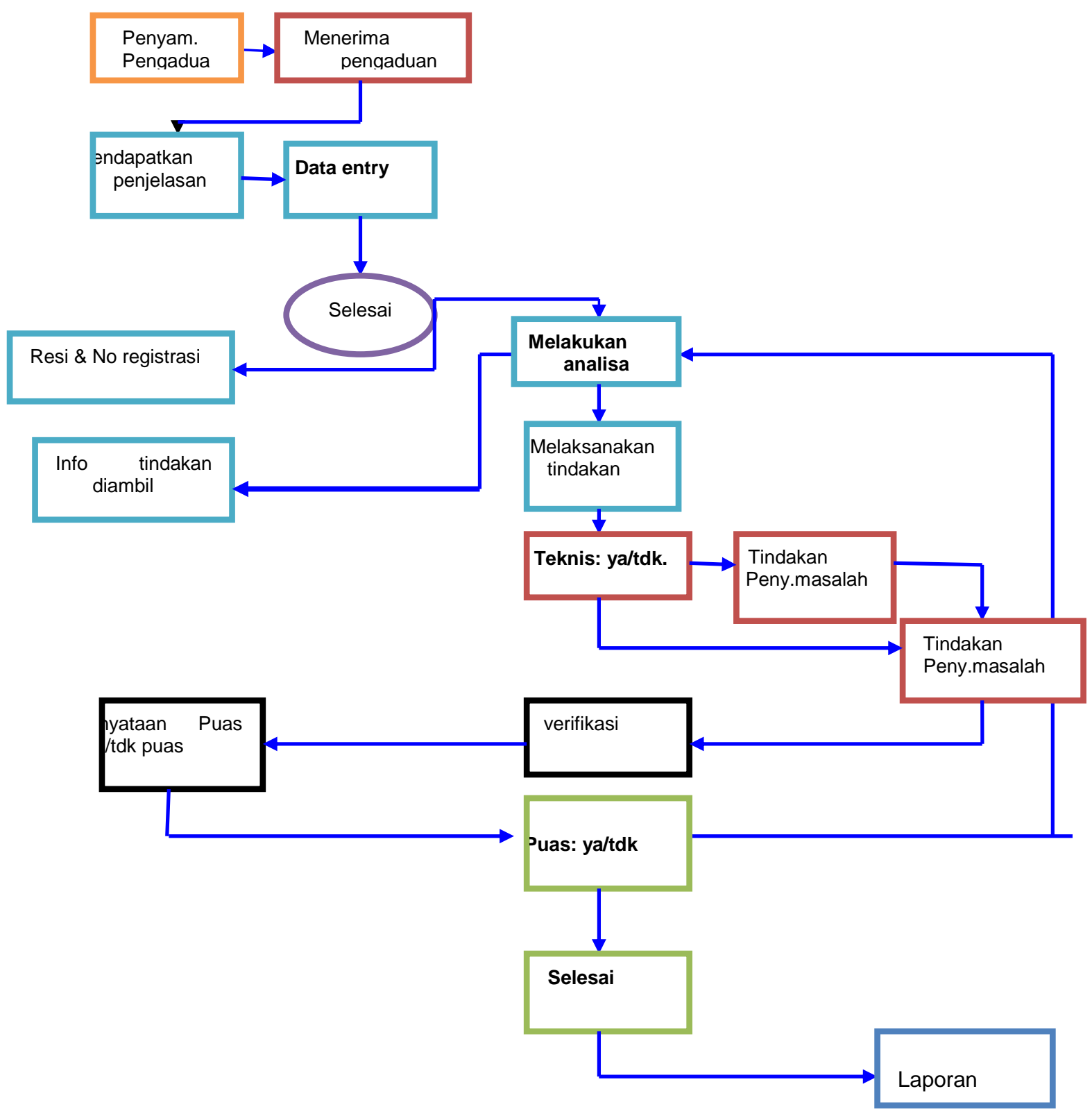

\section{Bagan 1. Mekanisme Pengaduan}

Pengaduan masyarakat terhadap birokrasi pelayanan perizinan terpadu Kota Kupang berdasarkan mekanisme yang telah ditetapkan oleh Birokrasi belum begitu efektif. Penyelesaian komplain masyarakat belum memberikan kepuasan, yang disebabkan karena sifatnya hanya ditampung saran-saran masyarakat di media kotak saran, yang kemudian diselesaikan sendiri oleh birokrasi tanpa melibatkan masyarakat, sehingga kurang begitu memberikan pengaruh positif terhadap persoalan pelayanan.

Reformasi Sistem dan Prosedur dalam pelayanan publik, berjalan secara optimal, yang jika dilihat dari persyaratan pelayanan dalam pengurusan dokumen izin terkesan 
masih memberatkan masyarakat, yang prosesnya melalui beberapa pintu yaitu Rukun Tetangga (RT), Rukun Wilayah (RW), Kelurahan, Kecamatan dan lembaga teknis. Jika dilihat dari aspek keterbukaan/transparansi dalam standar pelayanan masih memiliki kelemahan disebabkan karena SOP yang dimiliki oleh Birokrasi publik Kota Kupang merupakan produk birokrasi yang belum melalui uji publik dan belum dapat diakses melalui internet. Birokrasi publik Kota Kupang dalam menyusun SOP, belum sepenuhnya melibatkan perwakilan stakeholders secara umum akan tetapi PIAR NTT sebagai salah satu lembaga swadaya masyarakat yang selalu mendampingi Birokrasi publik Kota Kupang dalam penyusunan SOP, termasuk juga melakukan kajian kelembagaan, pada saat pembentukan lembaga baru pelayanan perizinan Kota Kupang.

Alokasi waktu yang dibutuhkan dalam proses penyelesaian dokumen izin belum sesuai dengan standar pelayanan karena kebanyakan pimpinan sering sibuk dengan rapat-rapat dan tugas kedinasan lainnya, sehingga mengalami keterlambatan.

Jika dicermati kondisi empirik ini, menunjukan bahwa SOP belum diterapkan secara efektif pada Birokrasi Pelayanan Perizinan Terpadu Kota Kupang, hal ini terlihat bahwa prosedur yang masih berbelit, penyusunan SOP yang belum melibatkan stakeholders, sehingga keberpihakan SOP lebih pada birokrasi ketimbang kepada masyarakat sebagai pengguna layanan. Rangkuman perubahan/reform sistem dan prosedur seperti pada tabel berikut ini:

\section{Tabel 2 Sistem dan Prosedur dalam Birokrasi Pelayanan Publik di Kota Kupang}

\begin{tabular}{|c|l|l|}
\hline No. & \multicolumn{1}{|c|}{ Sebelum Reformasi (lama) } & \multicolumn{1}{c|}{ Sesudah Reformasi (Baru) } \\
\hline 1 & $\begin{array}{l}\text { Semua OPD di lingkup Pemerintah Kota } \\
\text { Kupang tidak memiliki SOP. }\end{array}$ & $\begin{array}{l}\text { Hampir semua OPD telah memiliki SOP, } \\
\text { termasuk Lembaga Pelayanan terpadu } \\
\text { Satu Pintu Kota Kupang. }\end{array}$ \\
\hline 2. & $\begin{array}{l}\text { Yang dominan adalah aparat bekerja hanya } \\
\text { berdasarkan tupoksi, tapi masih belum } \\
\text { jelas, lebih banyak perintah pimpinan. }\end{array}$ & $\begin{array}{l}\text { Walaupun SOP belum berjalan secara } \\
\text { optimal, dan membutuhkan pemahaman, } \\
\text { sehingga perlu sosialisasi. }\end{array}$ \\
\hline 3 & $\begin{array}{l}\text { Perintah dan disposisi pimpinan menjadi } \\
\text { dasar bagi staf dalam melaksanakan tugas. }\end{array}$ & $\begin{array}{l}\text { SOP menjadi dasar bagi pimpinan dan } \\
\text { staf dalam melaksanakan tugas. }\end{array}$ \\
\hline
\end{tabular}

Sumber: Hasil olahan data penelitian

Perubahan yang terkait dengan standar pelayanan, sebelum reformasi hampir semua Organisasi Perangkat Daerah (OPD) tidak memiliki SOP, yang dominan adalah aparat bekerja hanya berdasarkan tupoksi, yang belum begitu jelas, dan lebih banyak perintah pimpinan. Di era reformasi ada perubahan, dimana hampir semua OPD memiliki SOP, walaupun belum berjalan secara optimal, yang masih membutuhkan 
pemahaman, sehingga memerlukan sosialisasi secara berkelanjutan dengan dukungan anggaran yang memadai.

\section{KESIMPULAN}

Reformasi Sistem dan Prosedur dan atau Standar Operasional Prosedur belum memenuhi kriteria kesesuaian untuk menjawab kebutuhan pelayanan, secara efisien dan efektif. Aspek ini menekankan (1) Persyaratan pelayanan, (2) Keterbukaan standar pelayanan, (3) Waktu yang dibutuhkan dalam proses izin, (4) Kejelasan mekanisme pengaduan. Kriteria ini belum dapat dipenuhi sepenuhnya, karena belum diuji publik melalui seminar atau forum lainnya yang melibatkan stakeholders untuk penyempurnaan Standar Operasional Prosedur (SOP), yang merupakan produk Birokrasi Pelayanan Perrizinan Terpadu Kota Kupang. Standard Operasional Prosedur (SOP) yang merupakan arah dan penuntun yang jelas tentang pelayanan publik perizinan, yang belum melibatkan unsur masyarakat, dunia usaha, dan belum melalui uji publik. Birokrasi publik Kota Kupang masih menempatkan diri sebagai penguasa secara tunggal menetapkan berbagai ketentuan termasuk SOP dalam penerbitan pelayanan izin. Sementara masyarakat dan pelaku usaha hanya mengikuti apapun yang telah diputuskan oleh penyelenggara. Hal ini memperkuat pandangan Caiden 2011; Smith, 2007 bahwa Reformasi Birokrasi pada dimensi sistem dan prosedur kerja meliputi standard operating procedure, changing methods, processes, techniques, routes, functions, roles, contacts, controls, transparent

Penelitian ini membuktikan bahwa teori tersebut tidak dapat terjadi secara otomatis, karena masih memerlukan perbaikan terhadap standar operasional prosedur yang perlu melibatkan stakoholders sebagai dasar atau acuan dalam melaksanakan pelayanan publik. Data dan fakta penelitian ini menunjukan bahwa aspek-aspek yang harus diperhatikan dalam perbaikan standar operasional prosedur dalam pelayanan publik meliputi (a) kepastian jadwal pelayanan, (b) prosedur Pelayanan, (c) kecepatanan petugas pelayanan, (d) kedisiplinan petugas pelayanan, (e) persyaratan pelayanan, yang harus ditingkatkan dan diperbaiki untuk meningkatkan kualitas pelayanan perizinan. Berbagai kelemahan dalam penyelenggaraan sektor pelayanan publik yang belum sesuai tuntutan dan harapan masyarakat, keluhan masyarakat atas rendahnya kinerja pelayanan yang diberikan oleh pemerintah daerah baik pelayanan di bidang administrasi, pelayanan perizinan, karena masih melalui banyak pintu. Oleh karena itu 
SOP yang jelas, dan berpihak kepada publik dan mampu memberikan kemudahan dalam pelayanan publik.

\section{DAFTAR PUSTAKA}

Atmoko, Tjipto. (2006). Standar Operasional Prosedur (SOP) dan akuntabilitas kinerja pemerintah. Pusat Penelitian Kebijakan Publik dan Pengembangan Wilayah Universitas Padjadjaran.

Caiden, (1991). Administrative Reform Comes of Age. Walter de Gruyter, Berlin.

Dwiyanto, (2011). Reformasi Birokrasi. Gramedia, Jakarta.

Erende Pos (28 September 2011).

Hughes, Owen. (1998). Public Management and Administration: An Introduction. London, Macmillan Press Ltd.

Larmour (1988). Bank Dunia dan Negara-Negara berkembang. Dikutip dari: Parmusinto dan Latif (2011). Dinamika Good Governance di tingkat Desa: MAP, FISIP Universitas Riau, 11(1) Januari, pp.2.

Milles, Matthew B., A. Michael Huberman \& Saldana (2014). Qualitative data analysis: a methods sourcebook. Edition 3. SAGE Publications, Inc. Thousand Oaks, California 91320.

Pandie David dkk,. (2009). Survey POPI NTT. Lemlit Undana, Kupang.

Pollit, Christopher and Geert Bouckaert. (2000). Public Management Reform. Oxford university Press, New York.

-------,. (2004). Public management reform: A comparative analysis. Oxford: Oxford University Press.

Prasojo, Eko (2013). Mengembalikan Kepercayaan Publik melalui Reformasi Birokrasi, Inovasi Daerah, dan Peningkatan Daya Saing Daerah” Seminar Nasional Reformasi Birokrasi. PGSP. Diakses dari Internet tanggal 18 Pebruari 2014.

Robinson, J.A., and Parsons, Q.N., (2006). "State Formation and Governance in Botswana", Journal of African Economies, 15 (1): 100-140.

Sedarmayanti. (2010). Reformasi Administrasi Publik, Reformasi Birokrasi, dan Kepemimpinan masa depan. Refika Aditama. Bandung.

Sinambela, Rochadi, Ghaszali, Muksin, Setiabudi, Bima, Syaifudin. (2006). Reformasi Pelayanan Publik. Teori, Kebijakan dan Implementasi. Bumi Aksara. Jakarta. 
Smith, B.C. (2007). Good Government and Development. Palgrave Macmillan, New York.

Strauss, Anselm, L. (1987). Qualitative Analysis for Social Scientist. Cambridge University Press.

Tambunan, Rudi M. (2011). Pedoman Teknis Penyusunan Standard Oprating Procedures. Jakarta: Maiestas Publishing.

Thoha, (2009). Birokrasi Pemerintah Indonesia di Era Reformasi, Jakarta: Kencana Prenada.

World Bank (1992). Dikutip dari: Parmusinto dan Latif (2011). "Dinamika Good Governance di tingkat Desa”, MAP, FISIP Universitas Riau, 11(1) Januari, pp.12. 